\title{
コンピュータによるラジオイムノアッセイ検査 自動レポーティングシステム
}

\author{
滝沢正臣，丸山喜代次，井上千恵子，丸山 清，小林敏雄，酒井倫子* \\ 信州大学医学部附属病院放射線部, *同病院検査部 \\ 390 松本市旭3-1-1 \\ 1980年10月 1 日 受理
}

\begin{abstract}
このシステムは, 在来の RIA トータルシステムに加えて，検査結果および患者 IDを総合的にフ アイル・検索するための IBM 標準形式のフレキシブルディスク, 報告書自動作成のためのプリン タより構成される。RIAのロット単位で, RIA種目, 患者名等12項目がディスクに登録される。こ の登録データと, RIA の assay 結果とがデータ処理後つき合わされ総合的にファイルされる。ディ スクは, 他のコンピュータシステムと互換性を持っているため, 他の化学検査の結果と照合ができ る。RIA 検査結果は, 自動報告システムにより診療科宛の報告書となる。この方法により, RIA検 査の総合ファイルと検索，能率的かつ精度の良い検查報告が可能となった。
\end{abstract}

Key Words: radioimmunoassay test, total system, data processing, automatic reporting radioimmunoassay data base

\section{1.はじめに}

ラジオイムノアッセイ(RIA) 法による血中ホルモン の測定は, 検出感度の高いこと, 定量性の良いことで 他の検査法に優れ，このため測定可能な種目が急速に 増加しつつある。これに伴い, 病院内に拈ける日常検 査件数も増加している。現在では, 検査精度の向上と 能率化のために, RIA 検査にトータルシステムを採用 する施設が多くなっている。現在のところ, 固相法 ${ }^{1}$ を用い，特定の種目をほぼ完全に自動化するシステム が市販されるに至っているが, 最終段階での最も重要 な検查結果の報告書の作成は自動化されていない。

著者らは, 現在の一般に使われているRIAトータル システムに附加することにより, 検査報告書の自動作 成, 互換可能なフロッピーディスクシステムによる検 查結果の総合ファイル，データ検索等を行うことので きるシステムを開発し，当院に扣けるRIA日常検査に 役立てているので報告する。

\section{2. 装置および方法}

$$
2 \cdot 1 \text { ハードウェアについて }
$$

本システムのベースとなる RIA トータルシステム は, オートピペットステーション (61500型), 冷却遠 心器 (DPR-6000)，ガンマカウンタ (MSI 4/600) 拉 よびデータ処理システム $(9845 \mathrm{~A})$ により構成されて いる。ガンマカウンタは, マイクロプロセッサを内蔵
し 4 本の $\mathrm{NaI}$ デテクタによる並列測定が可能である。 外部へはタイプライタによる印字と紙テープ出力が行 われるほかは，データ処理システムとのオンラインも 可能であるが，ここでは，受付業務，処理時間のフレ キシビリティを考え，オフライン方式を採用した。ガ ンマカウンタより後のシステム構成をFig. 1 に示し た。ここで述べる報告書作成の自動化のために，とく に仕様したものを斜線により示した。すなわちフロッ ピーディスク装置 (FD), プリンタおよびンフトウェ アである。このうち FD を特別仕様としたのは, 9845Aの標準 FD が IBM 標準となっていないため, ファイルしたデータが，同一機種内でしか互換性がな く, 他のシステムへの入力や, 化学検査結果とのつき 合せが難しいためである。現実に，検査部に設置のデ

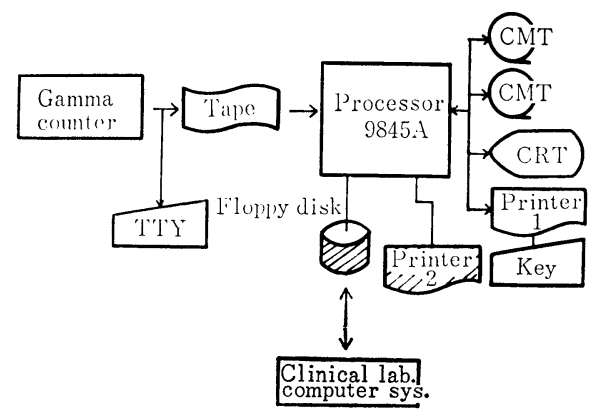

Fig. 1 Block diagram of a new RIA system added filing and reporting system. 
一タ処理システムへの RIA 検査結果の入力を行う計 画が立てられている。

プリンタ 2 は, RIA 検査結果の，各診療科への報告 書を作成する専用の低コストプリンタであり，トラク タフィードによるミシン目入りの紙に報告書を作成寸 る。80妳を印字速度 100 文字毎秒で印字し, カナ, 英 数字が利用できる。これに対しプリンタ 1 は感熱式の プリンタで, RIAデータ処理の較正曲線やデータの印 字を行らために使用される。処理システムの一部を Fig. 2 に示した。

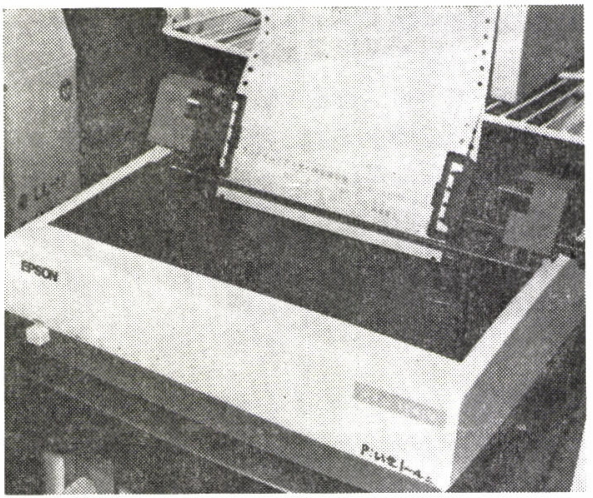

Fig. 2 Printer of the report to clinical department.

\section{$2 \cdot 2$ ソフトウェアについて}

データ処理括よび報告書作成は，Fig. 3 亿示すごと きフローによって行われる。このうち，在来の RIA データ処理は (b) の部分で行われている。血清の受付 時の検査依頼書による，データ処理システムへの患者 名等 (ID) の入力とファイル作成 (a), RIA 検查結果 (b)と，患者 ID との照合扣よび最終ファイル作成执よ び報告書作成(c)，検査データからのグラフ作成，患者 リストのプリント(d)に分かれる。

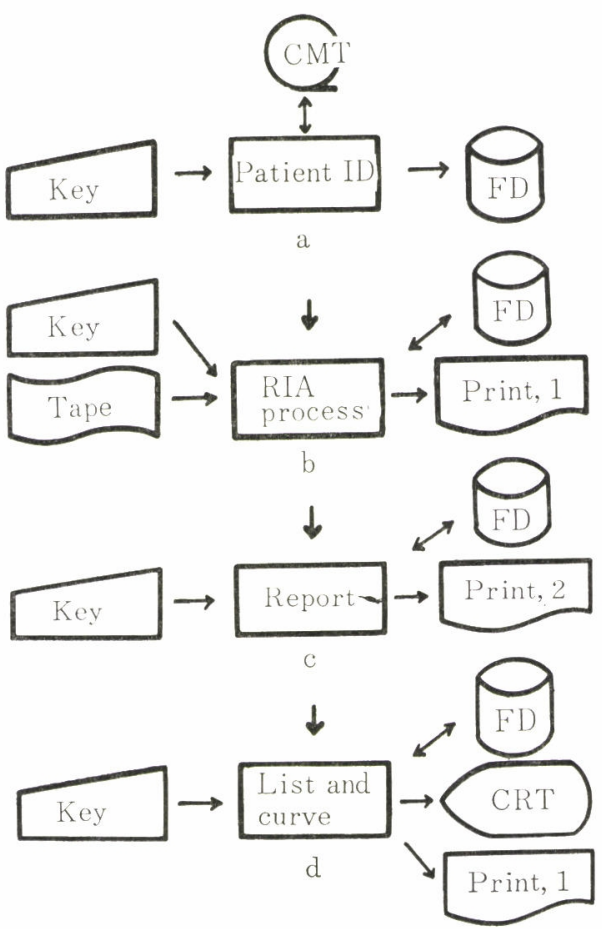

Fig. 3 Procedure of the RIA data processings with filing and reporting.

(a)では，受付けられた血清を測定順にそろえたのち， Table 1 の各項目について, 同表中央の文字数の種別 扣よび範囲内で処理システムにキーインする。患者番 号を使っていないのは, 統一番号がないのと, 番号によ

Table 1 Key-in parameters at the time of reception for RIA serum sample

\begin{tabular}{|c|c|c|c|c|}
\hline & Parameters & Contents & $\begin{array}{l}\text { Number of } \\
\text { bytes }\end{array}$ & Note \\
\hline 1 & Reception date & Within 6 numeric codes & 2 & \\
\hline 2 & Kind of RIA test & Within 4 alpha-numeric codes & 2 & \\
\hline 3 & Patient name & Within 15 alpha-numeric \& Kana codes & 17 & \\
\hline 4 & Sex & "M" or " $F "$ & 1 & \\
\hline 5 & Age & Within 2 numeric codes & 2 & \\
\hline 6 & Doctor name & Within 8 alpha-numeric codes & 10 & \\
\hline 7 & Department & Within 4 alpha-numeric codes & 2 & \\
\hline 8 & Floor & Within 5 alpha-numeric codes & 7 & \\
\hline 9 & Number of sample & Within 2 numeric codes & 2 & \\
\hline 10 & Sampling time & Within 4 numeric codes & $4 \mathrm{~N}$ & N: Number of sample \\
\hline 11 & Comments & Within 50 alpha-numeric \& Kana codes & 52 & involves normal value \\
\hline
\end{tabular}


るデータ検索は実用上使いにくいので使用せず，患者 名等により検索できる方法をとった。表中の測定数と は,インスリンのごとく糖負荷時の変化を測定する場 合で,一患者当たりの検体数が数本以上の場合に, 経 過時間とともに入力される。キーインの能率を向上さ せるため, 測定種目や測定日等, 同一内容が続いた場 合に，入力を省略してつぎに進む機能を附加した。1

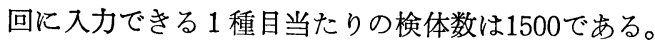
検査種目や科名等, 今後増加すると考えられる項目に 関しては, ソフトウェアの最小限の手直しで払張でき るように配慮されている。

キーより入力された患者 ID に関するデータは，い ったんカセットテープに保管され, 打込み終了後フロ ッピーディスク上に転送される。受付に関する ID の 入力作業は, RIA 検査のどの時点でも行うことが可能 である。ガンマカウンタからの測定データは紙テープ で得られるため, この紙テープを処理システムに入力 してデータ処理を実行する時点で受付データのつき合 せと照合が実施される。

(b)は一般的に行われている RIA データ処理 ${ }^{2), 3)}$ の部 分である。linear spline, log-spline, logit-log, 4-parameter 等が利用でき, あらかじめ登録された各種目ご との protocol に従って処理が実行される。紙テープリ ーダより入力された assay 結果と, フロッピーディス クにファイルされている，そのキットについての ID との照合は, RIA 種別, および測定日であり，2つの キーワードが一致しないと, 双方のデータを最終的に 合成することができない。フロッピーディスクは両面
倍密度のものを用いて沶り，両面で1024キロパイトの データをファイルできる。1枚当たり 2190 テスト分の データがファイルできるが，ディスクシートがェラー を起こした場合の代替ファイルのためのファイルスペ 一スが若干用意されている。

(c)は，ディスクにファイルされたデータを読み出し て，診療科に対する測定報告書を作成する部分であ る。報告書専用プリンタには, Table 2 のごとき項目 が出力される。英数字のみでは分かり難いので, 患者 名をはじめとして，カナ文字を積極的に用いている。 ただしカナでは，アルファベットとカナ文字の切替コ ードが必要であり，その分だけ打込む文字数が少なく なる。スタンダードサンプルの結果はプリントされな いが，プール血清のデータは印字される。Table 2 に 報告書の印刷項目を示した。印字速度は, 一報告書当 たり40〜60秒である。

(d)では，各キットごとの測定リストの印字を行った りまた統計処理を行ら。また，ホルモン量の経時変 化, 薬物負荷等による変動等の複数のデータをカーブ 上に表示するプログラムがある。ディスクファイルの 内容を確認するプログラムも利用できる。現在, ディ スクファイルの内容を, 特定の 2 項目以上のキーワー ドにより検索できるプログラムや，多種目の同時報告 書の作成を行うプログラムも作成中である(Table 3)。 (a)〜(d)の各プログラムは Basic 言語で記述されてい るので, 改良やプログラムの新開発は比較的容易であ り, 若干のソフトウェアの知識により, プログラムの 使い難い点などは改良を行っている。

Table 2 Filing and reporting parameters for RIA test

\begin{tabular}{ll|l|l}
\hline \multicolumn{1}{c|}{ Parameters } & \multicolumn{1}{c}{ Contents } & \multicolumn{1}{c}{ Note } \\
\hline 1 Kind of RIA test & 4 numeric characters & Example; \\
2 & Department & 4 alpha-numeric characters & IRI (insulin) \\
3 & Doctor's name & 8 alpha-numeric characters & \\
4 & Patient's name & 15 alpha-numeric characters & \\
5 & Sex & $0 \sim 99$ & \\
6 & Age & 8 numeric characters & \\
7 & Reception date & $0.0 \sim 99999.0$ & \\
8 & Results of RIA test & $1 \sim 9999$ & \\
9 & Sampling time & $0.0 \sim 100.0 \%$ & \\
10 & Variance of RIA data & 8 alpha-numeric characters & \\
11 & Measurement date & Same above & \\
12 & Technician's name & 10 alpha-numeric characters & \\
13 & Normal value of its RIA test & 52 alpha-numeric characters & \\
14 & Comments &
\end{tabular}


Table 3 List of the program name in our RIA data processing

\begin{tabular}{c|c|l|c}
\hline Program name & New, Old & \multicolumn{1}{|c}{ Contents } & Note \\
\hline INT & $\mathrm{N}$ & Make the IBM format with 256 bytes/sector & disk initialize \\
REC & $\mathrm{N}$ & Input patient identification data to disk system & conventional RIA \\
RIA & $\mathrm{O}$ & Measurement and data processing RIA data & \\
LST & $\mathrm{N}$ & Make a report to the clinical department & \\
GRP & $\mathrm{N}$ & Plotting a time activity curve & \\
DRE & $\mathrm{N}$ & Dump the data on the disk & \\
PLS & $\mathrm{N}$ & Prints a list of the RIA test with patient identifications & \\
DLI & $\mathrm{N}$ & Prints a list of files on the disk \\
SER & $\mathrm{N}$ & Retrieval and statistical analysis of filed data &
\end{tabular}

\section{3. 結 果}

Fig. 4 に, 受付時の患者データの入力状況を示し た。結果はキット単位でフロッピーディスクシートに 記録される。カナ文字と混合のキーボード操作は, 慣 れないと時間がかかるが，習熟により次第に短縮され る。現在では 100 件の患者データの打込みに約 60 分を 要している。著者らの施設では, 受付専任職員がいな いため, これらのデータは技術職員（放射線技師, 臨 床検査技師）が直接コンピニータに入力している。

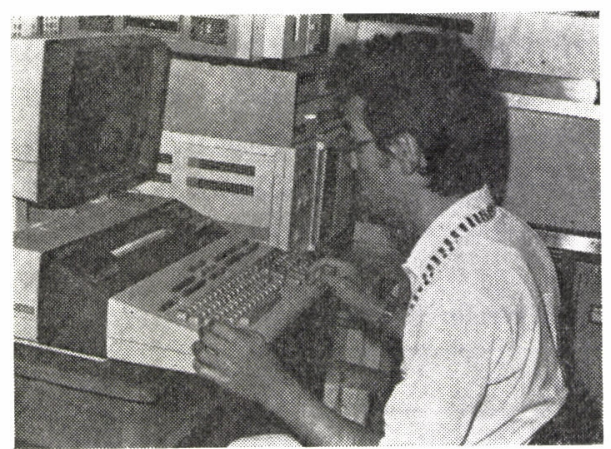

Fig. 4 Patient identifications are registered by the technician to the computer.

Fig. 5 に RIA 検査依頼書(上)と, 報告書(下)を示 した。印刷される報告書は, 測定者による誤り点検の らえで，そのまま各科に渡される。RIA室での記録， 医事課への報告は一覧表により行われている。

Fig. 6 は，血糖負荷によるインスリンの経時変化を 自動プロットした例を示す。この曲線は, 報告書とと もに受持医に渡される。

4. 考察

ラジオイムノアッセイ検查に扎けるトータルシステ

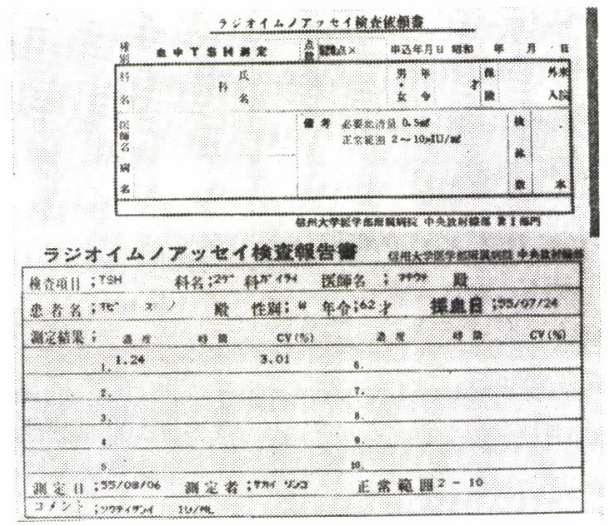

Fig. 5 Two sheets of RIA test: Order form of RIA test (top) and reporting form of the result (bottom).

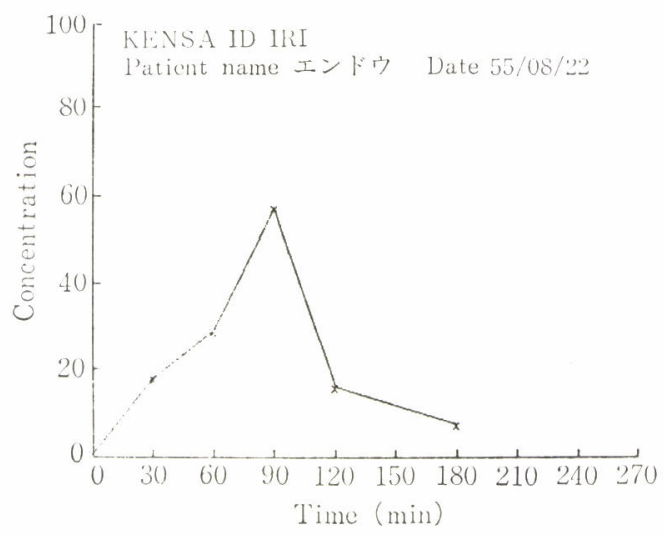

Fig. 6 A time activity curve has been made by the system: Insulin time activity curve by the test of dextrose loading (amenorrhea).

么の普及はめざましい。現在では, RIA 検査に独立し たガンマカウンタを用いることはむしろ少なく，大半 はトータルシステムが用いられている。現在でのトー 
タルシステムに拈ける最大のネックは, $\mathrm{BF}$ 分離に遠 心分離を用いていることである。固相法を用いた遠心 分離によらず測定を自動的に行うシステムが市販され ている。このシステムで測定できるRIA種目は現在の ところ少ないが，抗体のコーティング技術が進歩すれ ば測定可能種目が増えることが予想される。このよう な自動システムに拈いても, 現在十分でないのは, 受 付時の血清の分離・分類整理とその測定データとのつ き合せ, 報告業務の自動化の問題である。これは一般 化学検查に拉ける自動システムにも共通の問題であ る。検体チューブにバーュードをつけて行ら方法もよ い方法と思われるが，そのシステムは化学検査には採 用されていない。したがって現在のところ血清の分 類・整理は人手により実施する以外に方法がない。著者 らの施設でもこの部分は人手に頼っている。この作業 は時間がかかり，しかも誤りが多いのでよい方法の開 発が望まれる。

血清の整理ができた場合, 通常は検查依頼者をコピ 一式にして，検査結果を 2 枚目または 3 枚目に書く方 法が通常行われているが，この方法は患者名等の記入 に関する記入䛊りは除かれる。しかし，検査結果のリ スト作成, 患者 ID とのつき合せは手により行ら必 要があり, 転記ミスの可能性, 能率の低下が生ずる。 患者データのフロッピーディスクへのファイルは, 報 告の能率化，転記ミスをなくすことばかりでなく，迅 速なRIA 検查結果の検索などを可能とする。したがっ $\tau$, 多種目検査の同時報告や, また, 他の化学検査と
の同時報告等への拡張を期待できる。コンピュータに より印刷された報告書は, 報告を受ける医師にとって 読みやすく，信頼性が向上するものと考えられる。

今後の問題として, ディスクからの多次元データの 検索, 長時間追跡データによる曲線作成の自動化, 異 常データの自動抽出による精度の向上等のためのプロ グラム開発を行いたいと考えている。

\section{5. 結 論}

RIA 検査に拈ける受付とデータファイル，報告書の 作成をパーソナルコンピュータシステムにより行うシ ステムを開発した。このシステムにより, RIA検査デ 一タの集中的なファイル, 検査報告書作成の自動化, 経時測定結果の作表等が自動化され，RIA検査に拈け る能率向上と検査データの迅速な検索が実現された。

システムの開発にあたり, セントラル科学貿易, 日 本システム技術にご協力をいたたいた。

\section{文献}

1) Catt, K. and Tregear, G.W.: Science, 153, $1570 \sim 72$ (1967)

2) Rodbard, D. and Lewald, J.E.: Act. Endocrinol., (Suppl.) 147, 79 (1970)

3) System 45 software manual, Vol. 1: Clinical laboratory library, Heulett-Packard 


\title{
Abstract
}

\section{Development of an Automatic Reporting System for Radioimmunoassay Test}

\author{
Masaomi Takizawa, Kiyoji Maruyama, Chieko Inoue, \\ Kiyosi Maruyama, Toshio Kobayashi and Rinko SaKaI* \\ Department of Radiology and *Clinical Laboratory, Shinshu University Hospital \\ Asahi, Matsumoto-shi, Nagano Pref. 390, Japan
}

The system consists of a conventional RIA total system with a desk-top computer system, and a filing and reporting system of the RIA data with a flexible disk and a printer. Patient's identification is registered in the computer at the time of reception to RIA test. Their identifications are, reception date, name of RIA test, patient name, age, sex, doctor's name, name of clinical department, in- or out-patient, number of samples and it's sampling time, examination date of assay and comments included normal value. These data are recorded to a flexible disk sheet, and are combined with RIA examination data, when data process of radioimmunoassay finished.

Result of the RIA test is automatically printed by the printer. Printed parameters are results of examination with standard deviation, and above descrived patient identifications. If necessary, time activity curves of the density are plotted too. Accurate and automatically reporting system has been applied to the routine RIA test.

(Received October 1,1980) 